\title{
Wybrane konteksty edukacji międzykulturowej na Lubelszczyźnie
}

Streszczenie: Artykuł jest omówieniem dwóch sposobów włączania i rozwijania zadań edukacji międzykulturowej na Lubelszczyźnie. Pierwszy - dotyczy praktycznych działań prowadzonych w szkołach na różnych poziomach kształcenia, a drugi - koncepcji studiów podyplomowych w zakresie edukacji europejskiej, regionalnej i międzykulturowej realizowanych w Instytucie Pedagogiki Uniwersytetu Marii Curie-Skłodowskiej. Stanowi on również refleksję nad możliwościami wykorzystania potencjału kultury lokalnej (materialnej, symbolicznej, społecznej) do tworzenia autorskich projektów szkolnych i programów nauczania realizujących cele edukacji międzykulturowej.

Słowa kluczowe: kultura lokalna, edukacja regionalna, kształcenie międzykulturowe

\section{Wprowadzenie}

Od połowy ubiegłej dekady wyraźnie zaznaczył się ważny trend w funkcjonowaniu szkół związany z ich uczestnictwem w projektach finansowanych ze źródeł unijnych. Wsparcie dotyczyło i nadal dotyczy ogromnego wachlarza możliwości: od tworzenia nowej bazy dydaktycznej czy sportowej, poprzez wyposażanie pracowni tematycznych, jak też realizację działań wyrównujących braki edukacyjne czy wychowawcze uczniów. Słowo „projekt” na stałe weszło do słownika myślenia o edukacji (na różnych poziomach - przedszkola, szkoły podstawowe, gimnazja itd. i wielu obszarach), a w konsekwencji planowania nowatorskich edukacyjnych rozwiązań. Sprzyjała im poszerzająca się równolegle oferta nieodpłatnego kształcenia nauczycieli, zwłaszcza z terenów wiejskich i miejsko-wiejskich, gwarantując wszechstronne podnoszenie i doskonalenie kompetencji.

Strategia "myślenia i działania projektowego" została spożytkowana w Instytucie Pedagogiki w Uniwersytecie Marii Curie-Skłodowskiej w Lublinie celem utworzenia studiów podyplomowych „Nauczyciel europej- 
ski - studia podyplomowe w zakresie edukacji europejskiej, regionalnej i międzykulturowej"1. Podstawowym przyczynkiem do powołania tej formy kształcenia był zdiagnozowany problem niskich kompetencji międzykulturowych nauczycieli województwa lubelskiego.

Nabywanie kompetencji międzykulturowych przez nauczycieli Lubelszczyzny uznano za istotne z kilku powodów:

- wejścia Polski w struktury unijne i wynikającymi stąd procesami integracji,

- historycznej wielokulturowości Lublina i województwa lubelskiego,

- regionalnym zróżnicowaniem kulturowym (np. ziemia chełmska, zamojska, bialska),

- obecności cudzoziemców wynikającej z napływu uchodźców i studentów cudzoziemskich,

- intensywnych kontaktów kulturalnych z Ukrainą.

Te czynniki stworzyły i tworzą ogromny potencjał do realizowania zadań edukacji regionalnej, międzykulturowej i europejskiej na podstawie doświadczania kulturowego otoczenia. Należy w tym miejscu podkreślić, że Lubelszczyzna współcześnie ${ }^{2}$ - zdaniem socjologów - nie może być traktowana jako twór historyczny czy nawet geograficzny. W związku z wprowadzeniem 1 stycznia 1999 roku nowych granic województwa lubelskiego można wyróżnić takie subregiony, jak: Wyżyna Lubelska, Południowe Podlasie, Powiśle Lubelskie, Chełmszczyzna i Zamojszczyzna.

Realizacja studiów podyplomowych miała również ogromną wartość badawczą. Poprzez narracje uczestników pozwoliła na zebranie opinii o przyczynach niskich kompetencji międzykulturowych nauczycieli województwa lubelskiego oraz skali wykorzystania treści edukacji regionalnej, europejskiej i międzykulturowej w szkołach.

1 Szerzej o organizacji i realizacji studiów podyplomowych „Nauczyciel europejski - studia podyplomowe w zakresie edukacji regionalnej, europejskiej i międzykulturowej" w moim artykule: Akademickie ksztatcenie pedagogów wobec perspektywy wielokulturowości. W: A. Paszko (red.): Edukacja międzykulturowa w Polsce wobec nowych wyzwań. Kraków 2011, Stowarzyszenie Willa Decjusza, s. 261-277.

2 M. Dziekanowska: Tożsamość regionalna mieszkańców Lubelszczyzny. Raport z badań. W: M. Dziekanowska, J. Styk (red.): Region w koncepcjach teoretycznych $i$ diagnozach empirycznych. Lublin 2008, Perfecta info, s. 147-194. 


\section{1. „Nauczyciel europejski” - cel kształcenia}

Koncepcja kształcenia na studiach podyplomowych opierała się na stworzeniu takiej przestrzeni oddziaływań, w której możliwe będzie optymalne nabycie przez nauczycieli kompetencji z obszarów edukacji europejskiej, regionalnej i międzykulturowej.

Przyjęto za Jerzym Nikitorowiczem, że edukacja europejska to „[...] kształcenie i wychowanie ludzi, którzy realizują i będą realizować ideały zintegrowanej Europy. Byłoby to przygotowanie profesjonalistów, którzy ceniliby wartości prawa europejskiego, wspólnego rynku, wspólnych instytucji, zasad demokracji i społeczeństwa europejskiego” ${ }^{3}$. Celem tej edukacji jest „[...] ukształtowanie nowoczesnego, demokratycznego społeczeństwa sprawiedliwości i postępu, popartego bogactwem zróżnicowania kulturowego" ${ }^{4}$. Z kolei celem konstruowania programów edukacji regionalnej „jest budowa Europy »małych« ojczyzn przez rozpoznanie i rekultywację kultur lokalnych sytuowanych w kontekście kultur europejskich, wspomaganie procesów emocjonalnej identyfikacji uczących się ze środowiskiem lokalnym i otaczającym regionem, wspomaganie poczucia tożsamości narodowej, upowszechnianie wiedzy o specyficznych problemach i potrzebach danego regionu, pobudzanie samorządności, aktywności społecznej, kulturalnej i obywatelskiej jego mieszkańców"5. Edukacja międzykulturowa natomiast tworzy platformę dialogu dla świadomego wartości własnego regionu obywatela Europy.

Zamysł połączenia w jedną ścieżkę kształcenia trzech obszarów edukacji: europejskiej, regionalnej i międzykulturowej opierał się na przekonaniu o ich nierozłączności i współzależności. Zespolenie edukacji europejskiej - wspomagającej procesy integracji europejskiej z edukacją regionalną - eksponującą kulturowe zróżnicowanie regionów oraz edukacji międzykulturowej nastawionej na rozumienie i wyjaśnianie interakcji między kulturami, służy wzajemnemu uzupełnianiu, wzbogacaniu i podtrzymywaniu różnorodności kulturowej. Edukacji międzykulturowej nadano tu wartość nadrzędną, gdyż

3 J. Nikitorowicz: Edukacja regionalna i międzykulturowa. Warszawa 2009, WAiP, s. 240.

4 Tamże, s. 237.

5 K. Błeszyńska: Teoretyczny status edukacji międzykulturowej. W: J. Nikitorowicz, A. Sadowski, D. Misiejuk (red.): Edukacja międzykulturowa. „Pogranicze. Studia Społeczne”. T. XVII, cz. I. Białystok 2011, UwB, s. 45. 
wprowadza możliwości życia poza spektrum własnej kultury, a tym samym lepszego zrozumienia roli historii i życia we wspólnych kontekstach tworzenia znaczeń i zachowań.

\section{Określenie kompetencji międzykulturowych nabywanych w trakcie studiów}

Kompetentny nauczyciel w wymiarze europejskim to taki, który, ogólnie ujmując, posiada wiedzę i umiejętności związane z procesem uczenia się/ nauczania oraz predyspozycje do kształtowania postaw uczniowskich ${ }^{6}$. W ramach tych głównych kryteriów wymienia się szczegółowe warunki, którymi winien się wykazać na wszystkich poziomach kształcenia bez względu na specyfikę przedmiotu, który prowadzi. Jedną z głównych idei realizowanych przez edukację jest zachowanie tożsamości kulturowych przy jednoczesnym szacunku dla „Inności”. Dokumenty unijne wspierają podtrzymywanie i rozwijanie bogactwa Europy, jakim jest kulturowa różnorodność. Na europejski ideał wychowania składają się m.in. następujące elementy:

- „wychowanie człowieka do demokracji i umiejętności korzystania z praw człowieka, nabywanie świadomości obywatelskiej,

- edukacja dla pokoju, kształtowanie uczuć szacunku i przyjaźni między narodami,

- wychowanie w duchu tolerancji rasowej, społecznej, religijnej, politycznej, otwartości na „Innych”, wzajemnej informacji, porozumienia, dialogu, pomocy w sytuacjach zagrożenia rozwoju człowieka,

- ochrona kultur rodzimych, przeciwstawianie się niebezpieczeństwom wynikającym z kultury masowej i narzuconej, (...)" ${ }^{\prime}$.

Kompetencje międzykulturowe ${ }^{8}$ potraktowano bardzo szeroko: jako zespół kompetencji umożliwiających funkcjonowanie w środowiskach zróżnicowanych kulturowo, służące nauczycielom do efektywnego wspierania uczniów w procesie socjalizacyjnym (enkulturacyjnym).

6 M. Sielatycki: Kompetencje nauczyciela w Unii Europejskiej. „Trendy. Uczenie się w XXI wieku" 2005, nr 3, s. 7.

7 J. Nikitorowicz: Edukacja regionalna i międzykulturowa. cyt. wyd., s. 240.

8 K. Błeszyńska: Teoretyczny status edukacji międzykulturowej. W: J. Nikitorowicz, A. Sadowski, D. Misiejuk (red.): Edukacja międzykulturowa. „Pogranicze. Studia Społeczne", T. XVII, cz. I. cyt. wyd., s. 42-43. 
Przy określaniu kompetencji międzykulturowych nauczycieli założono, że ich praca ma znamiona twórczości i nastawiona jest na interakcyjność. Przy tak intensywnie zmieniającej się rzeczywistości nie wystarcza już posiadanie pewnych cech psychofizycznych, intuicji i doświadczenia, lecz niezbędny jest odpowiedni układ wiadomości i umiejętności uzyskanych po ukończeniu pewnego cyklu kształcenia. Do tworzenia ram ogólnych umiejętności nauczycieli posłużyła typologia kwalifikacji animatora kultury Opaschowskiego ${ }^{9}$. Wydaje się, że jest ona we wszystkich obszarach adekwatna do roli, jaką współcześnie mają pełnić nauczyciele. Są to:

- umiejętności umożliwiania komunikacji,

- umiejętności wyzwalania twórczości,

- umiejętności społeczno-integracyjne,

- umiejętności ułatwiania uczestnictwa i współdziałania w życiu kulturalnym ${ }^{10}$.

Takie podejście oddawało perspektywę zdobywania wiedzy z wyżej określonych obszarów i kształtowania u ucznia (uczniów) postaw aktywnych wobec świata, siebie i innych ludzi. Nie bez znaczenia na myślenie o kształceniu nauczycieli miał fakt długoletniej współpracy z ekspertami w zakresie pedagogiki kultury, animacji społeczno-kulturalnej, marketingu w działalności kulturalnej i zarządzania kulturą ${ }^{11}$.

Wobec przyjęcia takiej perspektywy założono, że w programie studiów ważne będą przedmioty odnoszące się do następujących grup umiejętności:

- umiejętności diagnozowania potrzeb, zdolności, motywacji i możliwości uczniów i grup ze środowiska lokalnego; problemów środowiska lokalnego i jednostek dyskryminowanych; krytycznej oceny efektów prowadzonych działań,

- umiejętności komunikacyjne - prowadzenie dialogu, nawiązywania interakcji, zaciekawiania uczniów/społeczności lokalnych Innością i mó-

9 E. Dąbrowska: Osoba animatora i koncepcja jego ksztatcenia. W: J. Gajda, W. Żardecki (red.): Dylematy animacji kulturalnej. Lublin 2001, UMCS, s. 130-131.

10 A. Świdzińska: Akademickie kształcenie pedagogów wobec perspektywy wielokulturowości. W: A. Paszko (red.): Edukacja międzykulturowa w Polsce wobec nowych wyzwań. cyt. wyd., s. 265-266.

11 W tym miejscu chcę podkreślić rolę Koleżanek i Kolegów z Zakładu Pedagogiki Kultury Uniwersytetu Marii Curie-Skłodowskiej w Lublinie: dr. hab. Dariusza Kubinowskiego prof. UMCS, dr Barbary Jedlewskiej, dr. Wojciecha Bobrowicza, dr Urszuli Bylicy i mgr. Bartosza Dąbrowskiego, których merytoryczne uwagi pomogły mi w nadaniu ostatecznego kształtu omawianym studiom podyplomowym. 
wienia o Inności; wyrażania własnych poglądów w sposób nieraniący uczuć; komunikowania się w sposób werbalny i niewerbalny z jednostkami i grupami,

- umiejętności organizacyjne związane z doborem treści, form, metod i środków do działania w środowisku lokalnym i w kontaktach międzykulturowych; doborem współpracowników, instytucji i organizacji wspierających; doborem adekwatnych form promocji podjętych działań; stosowaniem strategii marketingowych w kulturze i edukacji,

- umiejętności pedagogiczno-psychologiczne związane z praktycznym zastosowaniem nabytej wiedzy z zakresu metodyk: edukacji regionalnej, międzykulturowej i europejskiej we wdrażaniu zadań dydaktyczno-wychowawczych; stosowania wiedzy psychologicznej w międzykulturowych interakcjach ${ }^{12}$.

Kompetencje, które powinien nabyć uczestnik studiów podyplomowych w zakresie edukacji europejskiej, regionalnej i międzykulturowej, sformułowano jako efekty kształcenia, które należy traktować jako propozycję, wymagającą dalszego udoskonalania.

W zakresie wiedzy nauczyciel, który ukończył studia:

- zna podstawową terminologię kulturową, społeczną i edukacyjną odnoszącą się do teorii i praktyki edukacji europejskiej, regionalnej i międzykulturowej oraz zarządzania działalnością kulturalną,

- ma uporządkowaną wiedzę podstawową z zakresu dyscyplin nauk humanistycznych i społecznych, właściwych dla edukacji europejskiej, regionalnej i międzykulturowej, zorientowaną na zastosowanie praktyczne,

- zna i rozumie różne koncepcje edukacji europejskiej, regionalnej i międzykulturowej,

- ma podstawową wiedzę o systemie oświaty polskiej i europejskiej oraz instrumentach wdrażania działań praktycznych,

- ma podstawową wiedzę o wybranych strukturach i instytucjach społecznych oraz rodzajach więzi społecznych, w tym regionalnych i międzykulturowych,

- ma elementarną wiedzę z zakresu zarządzania humanistycznego, w tym kulturą regionu, oraz współczesnego marketingu, w szczególności w sferze kultury i edukacji,

12 A. Świdzińska: Akademickie kształcenie pedagogów wobec perspektywy wielokulturowości. W: A. Paszko (red.): Edukacja międzykulturowa w Polsce wobec nowych wyzwań. cyt. wyd., s. 266. 
- ma podstawową wiedzę o teorii i praktyce animacji kulturalnej, w tym szczególnie w zakresie animacji regionu,

- ma podstawową wiedzę o metodyce działalności regionalnej, europejskiej i międzykulturowej, w szczególności w zakresie animatorskim i menedżerskim,

- ma podstawową wiedzę o sposobach prowadzenia studiów i badań humanistycznych oraz społecznych, w szczególności o odbiorcach kultury regionalnej i diagnozowaniu ich potrzeb,

- ma podstawową wiedzę z zakresu wybranych obszarów aktywności człowieka na rzecz praw człowieka,

- ma wiedzę o procesach integracji, także w obszarze prawa oświatowego i polityki kulturalnej państw europejskich i Polski,

- ma wiedzę na temat wspólnot lokalnych oraz ich organizacji, w tym szczególnie oświatowych i kulturalnych,

- zna rolę przepisów prawa oraz ekonomicznych prawidłowości rządzących sferą kultury,

- ma wiedzę na temat psychologicznych aspektów kontaktów międzykulturowych w sferze jednostkowej i grupowych,

- ma wiedzę na temat znaczenia dziedzictwa kulturowego regionu i Europy dla społeczeństwa,

- ma wiedzę o normach politycznych, prawnych i kulturowych,

- zna warunki i formy uczestnictwa w życiu społecznym na różnych jego poziomach i kulturowych obszarach,

- dysponuje wiedzą o relacjach zachodzących pomiędzy instytucjami uczestniczącymi w procesach komunikowania międzykulturowego, w tym oświatowych i kulturalnych,

- ma wiedzę o roli człowieka w życiu społecznym i kulturowym oraz jego interakcjach z najbliższym otoczeniem w procesie rozwoju cywilizacyjnego,

- ma wiedzę na temat roli mediów i komunikacji społecznej w warunkach społeczeństwa informacyjnego, w tym roli stereotypów i uprzedzeń,

- ma podstawową wiedzę psychologiczną i pedagogiczną pozwalającą na rozumienie procesów rozwoju, socjalizacji, wychowania i nauczania w kontekście procesów międzykulturowych,

- ma wiedzę z zakresu psychologii międzykulturowej i metodyki edukacji europejskiej, regionalnej i międzykulturowej, popartą doświadczeniem w jej praktycznym wykorzystywaniu. 
W zakresie umiejętności nauczyciel, który ukończył studia:

- potrafi analizować i wyjaśniać zachowania człowieka oraz grup społecznych w interakcjach międzykulturowych,

- umie analizować i wyjaśniać mechanizmy funkcjonowania wspólnot lokalnych oraz grup kulturowych (np. naród, grupa etniczna),

- umie określić rolę edukacji i kultury w życiu społeczeństwa,

- potrafi wykorzystywać metody i techniki badawcze do analizy zjawisk społecznych w różnych kontekstach kulturowych i edukacyjnych,

- umie wskazać założenia różnych koncepcji i nurtów edukacji europejskiej, regionalnej i międzykulturowej oraz ocenić konsekwencje ich realizacji,

- posiada umiejętność występowania publicznego, dobiera rzeczowe argumenty i swobodnie formułuje odpowiedź na krytykę,

- wskazuje specyfikę różnych nurtów w obszarze edukacji europejskiej, regionalnej i międzykulturowej oraz dostrzega ich wpływ na praktykę oświatową i działalność kulturalną,

- posiada umiejętność prognozowania zjawisk na poziomie ogólnym oraz zagrożeń dla relacji międzykulturowych,

- wykorzystuje wskazania systemów aksjologicznych, reguł i norm kulturowych do poznania i oceny rzeczywistości społecznej,

- umie analizować i oceniać proces nabywania kompetencji kulturowych przez uczniów oraz dostrzegać ich implikacje w działalności edukacyjnej i kulturalnej,

- wyszukuje, analizuje, ocenia, selekcjonuje i wykorzystuje informacje ze źródeł i literatury przedmiotu,

- wskazuje i wyjaśnia zasady oraz wartości społeczeństwa obywatelskiego,

- potrafi docenić cywilizacyjny dorobek człowieka ze szczególnym uwzględnieniem kultury regionalnej i europejskiej,

- potrafi aktywnie i świadomie uczestniczyć w życiu społeczno-kulturalnym regionu oraz $\mathrm{w}$ dyskursie publicznym,

- dostrzega i ocenia społeczne oczekiwania dotyczące roli instytucji społeczno-kulturalnych oraz zagrożenia płynące z różnicy kulturowych etnosów,

- dostrzega relacje między edukacją europejską, regionalną i międzykulturową a zjawiskami historycznymi, ekonomicznymi, społecznymi, kulturowymi i ideologicznymi, 
- analizuje i ocenia treści przekazu medialnego oraz posiada umiejętność przygotowania wystąpienia publicznego,

- posiada umiejętności i kompetencje niezbędne do kompleksowej realizacji dydaktycznych, wychowawczych i opiekuńczych zadań szkoły, w tym do samodzielnego przygotowania i dostosowania programu nauczania w zakresie edukacji europejskiej, regionalnej i międzykulturowej,

- wykazuje umiejętność uczenia się i doskonalenia własnego warsztatu z wykorzystaniem nowoczesnych środków i metod pozyskiwania, organizowania i przetwarzania informacji i materiałów z zakresu edukacji europejskiej, regionalnej i międzykulturowej,

- potrafi umiejętnie komunikować się przy użyciu różnych technik, zarówno z osobami będącymi podmiotami działalności pedagogicznej (uczniami podczas zajęć z zakresu edukacji europejskiej, międzykulturowej i regionalnej), jak i z innymi osobami współdziałającymi w procesie dydaktyczno-wychowawczym oraz specjalistami wspierającymi ten proces.

W zakresie postaw (kompetencji społecznych) nauczyciel, który ukończył studia:

- jest przygotowany do uczestniczenia w życiu publicznym oraz kreowania różnych form aktywności edukacyjnej i kulturalnej,

- jest świadomy znaczenia dziedzictwa kulturowego do interpretacji wydarzeń życia publicznego,

- ma potrzebę dalszego uzupełniania wiedzy oraz poszerzania i doskonalenia umiejętności,

- posiada ogólne przygotowanie do pracy w lokalnych społecznościach (organizacjach kulturalnych, fundacjach) i instytucjach edukacyjnych w zakresie wdrażania i zarządzania projektami kulturowo-edukacyjnymi,

- zachowuje się w sposób profesjonalny i etyczny w pracy zawodowej oraz publicznej działalności kulturalnej,

- jest przygotowany do kierowania zespołami ludzkimi, szczególnie uczniami, przy realizacji zadań edukacji europejskiej, regionalnej i międzykulturowej,

- jest przygotowany do aktywności w środowisku lokalnym, ma świadomość konieczności dostosowywania się do warunków kulturowych regionu i doskonalenia kwalifikacji zawodowych, 
- uznaje i szanuje różne punkty widzenia determinowane odmiennym podłożem kulturowym, społecznym i ideologicznym,

- charakteryzuje się wrażliwością etyczną, empatią, otwartością, refleksyjnością oraz postawami prospołecznymi i poczuciem odpowiedzialności,

- jest praktycznie przygotowany do realizowania zadań zawodowych (dydaktycznych, wychowawczych i opiekuńczych) wynikających z roli nauczyciela w zakresie edukacji europejskiej, regionalnej i międzykulturowej.

Kompetencje te zawarto w poszczególnych modułach przedmiotowych realizowanych w czasie dwóch semestrów w ramach 270 godzin dydaktycznych $^{13}$.

\section{Studia podyplomowe jako dialog o edukacji międzykulturowej w szkole}

Studia podyplomowe umożliwiły spotkanie nauczycielek i nauczycieli z różnych miejsc Lubelszczyzny. Uczestnicy byli nauczycielami pracującymi w szkołach podstawowych, gimnazjach, szkole zawodowej i liceach. Posiadali zróżnicowane doświadczenie w realizacji projektów czy działań z obszaru edukacji regionalnej, międzykulturowej i europejskiej.

Wspólne zajęcia stworzyły przestrzeń dzielenia się wiedzą o lokalnych różnicach kulturowych, doświadczeniami z pracy w realizacji projektów w szkołach i lokalnych społecznościach, pomysłami, jak lepiej wykorzystać potencjał regionu do działań międzykulturowych. Prowadzone dyskusje, głównie w ramach przedmiotów Edukacja regionalna z metodyka, Edukacja międzykulturowa $z$ metodyka, Edukacja europejska $z$ metodyka i Seminarium dyplomowe, zaowocowały ogólną diagnozą stanu i zakresu realizacji celów edukacji międzykulturowej w szkołach w oparciu o kulturę materialną, symboliczną i społeczną „małej ojczyzny” na Lubelszczyźnie. W narracjach nauczycieli przebijał wątek potrzeby uznania mocy kultury w konstruowaniu naszej rzeczywistości.

13 Szczegółowe omówienie programów zajęć zawarto w opracowaniu A. Świdzińskiej: Akademickie ksztatcenie pedagogów wobec perspektywy wielokulturowości. W: A. Paszko (red.): Edukacja międzykulturowa w Polsce wobec nowych wyzwań. cyt. wyd., s. 270-273. 
Zebrane informacje i opinie stały się źródłem wiedzy, obejmującej następujące zagadnienia:

1. Realizacja zagadnień problematyki szeroko rozumianej edukacji międzykulturowej w szkołach Lubelszczyzny była przede wszystkim wynikiem:

- pojawienia się dzieci uchodźców (od 2005 roku w ośrodkach dla cudzoziemców prowadzonych poza dużymi miastami, tj. Lublinem i Łukowem),

- możliwości finansowania pomysłów na rzecz procesów integracyjnych, które w większości dotyczyły rewitalizacji kultury lokalnej poprzez „odkrywanie” historycznej wielokulturowości miejsca,

- wejścia Polski w struktury unijne, a co za tym idzie, tworzenia Klubów Europejskich i nawiązania kontaktów ponadnarodowych w ramach szkół partnerskich lub podjęcia projektów partnerskich.

2. W województwie lubelskim - w opinii nauczycieli - pomoc merytoryczną w zakresie edukacji międzykulturowej oferują przede wszystkim organizacje pozarządowe (m.in. lokalne: Homo Faber, Stowarzyszenie „Dla Ziemi” oraz Polska Akcja Humanitarna, Centrum Edukacji Obywatelskiej), które we współpracy ze szkołami wdrażają większość projektów skierowanych na budowanie społeczeństwa obywatelskiego w zróżnicowanym kulturowo świecie. Nauczycielom brakuje wsparcia ze strony samorządów, Ministerstwa Edukacji Narodowej oraz Kuratorium Oświaty. Wsparcie to rozumiane jest jako wsparcie finansowe oraz egzekwowanie realizacji programów międzykulturowych, europejskich czy regionalnych od dyrektorów szkół oraz przygotowanie poradników metodycznych.

3. Istniejący w podstawie programowej zapis umożliwiający włączanie zadań edukacji międzykulturowej ${ }^{14}$ przekłada się na konkretne programy

14 Podstawa programowa wychowania przedszkolnego oraz kształcenia ogólnego w poszczególnych typach szkół z dnia 23 grudnia 2008 roku, opublikowana w dniu 15 stycznia 2009 roku w Dzienniku Ustaw nr 4, poz. 17: „W procesie kształcenia ogólnego szkoła podstawowa kształtuje u uczniów postawy sprzyjające ich dalszemu rozwojowi indywidualnemu i społecznemu, takie jak: uczciwość, wiarygodność, odpowiedzialność, poczucie własnej wartości, szacunek dla innych ludzi, ciekawość poznawczą, kreatywność [...], gotowość do uczestnictwa w kulturze. W rozwoju społecznym bardzo ważne jest kształtowanie postawy obywatelskiej, postawy poszanowania tradycji i kultury własnego narodu, a także postawy poszanowania dla innych kultur i tradycji. Szkoła podejmuje odpowiednie kroki w celu zapobiegania wszelkiej dyskryminacji”. 
wychowawcze szkoły, jeśli są w nich uczniowie cudzoziemscy. Sytuacja powoli ulega zmianie, ale dalej większość nauczycieli nie dostrzega wagi kształtowania kompetencji międzykulturowych u uczniów, bądź są one zawężane do kształtowania tożsamości regionalnej. Podstawowym rozwiązaniem jest napisanie projektu i pozyskanie funduszy. Jednakże wraz z jego zakończeniem kończą się również pieniądze na warsztaty, wycieczki czy materiały.

4. Nauczycielom brakuje wiedzy o szkołach realizujących projekty z zakresu edukacji regionalnej, międzykulturowej i europejskiej. Chcieliby mieć możliwość wspólnych spotkań i wymiany doświadczeń.

5. Nauczycielom brakuje wiedzy na temat publikacji o tematyce edukacji regionalnej i międzykulturowej. Nie korzystają ze źródeł internetowych, gdzie dostępne są materiały wymagające niewielkiej modyfikacji i adaptacji do lokalnych uwarunkowań kulturowych.

6. Nauczyciele nie wykorzystują lokalnych zasobów kultury materialnej, aby tworzyć wokół nich narrację o historii regionu. W większości szkół organizowane wycieczki nie mają przemyślanego celu edukacyjnego.

7. Nauczycielom brakuje krótkich form szkoleniowych, dzięki którym mogliby uzupełniać swoją wiedzę i podnosić umiejętności.

Opinie nauczycieli o poziomie i zakresie funkcjonowania idei edukacji międzykulturowej na Lubelszczyźnie dały impuls do prowadzenia dalszych analiz problemu kształtowania kompetencji międzykulturowych nauczycieli i uczniów na Lubelszczyźnie. Wstępna analiza działalności szkół uwzględniająca kulturowe zróżnicowanie regionu, Europy, świata wskazuje, że aktywne w tym obszarze są głównie szkoły w dużych miastach. Wynika to m.in. z faktu włączania się szkół w szersze przedsięwzięcia kulturalne cyklicznie prowadzone przez znane instytucje kultury. Małe szkoły wiejskie - dzięki aktywności swoich nauczycieli - starają się je organizować w miarę możliwości finansowych i logistycznych.

Należy podkreślić, że nauczyciele - pomysłodawcy „projektów” - są osobami aktywnie realizującymi swój zawód i poczucie misji. Poszukują wiedzy, nowych umiejętności i rozwiązań metodycznych, kontaktów do budowania sieci wsparcia i wymiany doświadczeń. Wdrażając swoje pomysły, aktywnie uczestniczą w życiu kulturalnym lokalnej społeczności, są animatorami działalności kulturalnej i wolontariackiej. Ale często czują się przeciążeni indywidualną odpowiedzialnością za podjęte przez siebie działania i nie znajdują zrozumienia, a co za tym idzie, wsparcia u swoich przełożonych 
i kolegów. Ten stan rzeczy wynika również z ilości zadań stawianych obecnie nauczycielom, co często artykułowano w trakcie dyskusji. Zdaniem nauczycieli, kształtowanie kompetencji międzykulturowych uczniów będzie miało miejsce nadal, jeśli włączą oni wypracowane metody i formy edukacji międzykulturowej na stałe do swojego programu wychowawczego. Zwracają uwagę również na pojawiające się poczucie zwątpienia i braku wiary we własne pomysły, które często hamuje rozwój indywidualnych koncepcji pracy z uczniami.

Wśród propozycji rozwiązań, które pojawiły się w wyniku dyskusji, należy wskazać:

- przyjęcie perspektywy „mezo” - lokalnej różnorodności kulturowej, w tym obecności cudzoziemców - obejmującej diagnozę potencjału kultury regionu i wypracowanie na tej podstawie długofalowych strategii edukacyjnych,

- zdiagnozowanie dotychczasowego stanu wiedzy, działań pomocowych i osiągniętych już efektów w celu implementacji,

- budowanie bazy „dobrych praktyk” - efektów osiąganych w wyniku działalności instytucji (w tym szkół) i organizacji pożytku publicznego,

- stworzenie ciała koordynującego działalność nauczycieli w zakresie edukacji międzykulturowej zmierzającą do integracji tego środowiska.

\section{Podsumowanie}

Studia „Nauczyciel europejski - studia podyplomowe w zakresie edukacji europejskiej, regionalnej i międzykulturowej" zostały uruchomione dzięki pozyskaniu finansowego wsparcia UE. Istniejąca ścieżka komercyjna tych studiów nie funkcjonuje z powodu niskiego zainteresowania problematyką (nie ma formalnego wymogu posiadania kompetencji przez nauczycieli w tym zakresie) oraz koniecznością ich indywidualnego finansowania przez zainteresowanych.

Realizacja tej formy kształcenia wymagała wskazania nabywanych przez nauczycieli kompetencji, które określono jako międzykulturowe. W oparciu o istniejącą teorię w zakresie edukacji regionalnej, międzykulturowej i europejskiej ${ }^{15}$ skonstruowano 22 efekty kształcenia w zakresie wiedzy, 20 w zakre-

15 T. Lewowicki: W poszukiwaniu modelu edukacji międzykulturowej. W: T. Le- 
sie umiejętności i $11 \mathrm{w}$ zakresie kompetencji personalnych i społecznych. Jest to autorska propozycja, która wymagać będzie doskonalenia czy adaptacji, choćby ze względu na przyjęcie innej perspektywy w konstruowaniu kwalifikacji nauczyciela niż animacja społeczno-kulturalna.

Nauczyciele, którzy realizowali studia podyplomowe „Nauczyciel europejski”, kierowali się potrzebą rozwoju swoich zainteresowań: chęcią pogłębienia posiadanej wiedzy, potrzebą nabycia nowych umiejętności i rozwiązań metodycznych, nawiązania kontaktów. $80 \%$ z nich realizowało już projekty z zakresu edukacji regionalnej, międzykulturowej lub europejskiej.

Spotkania nauczycieli w trakcie studiów można określić jako nieustanny „dialog kultur”. Wymiana wiedzy, doświadczeń i pomysłów aktywizowała grupę nie tylko w trakcie zajęć, ale przekładała się na podejmowane w szkołach inicjatywy edukacyjne (lekcje tematyczne, konkursy, projekty integracji społeczności lokalnej, poznanie kultury materialnej i symbolicznej regionu).

Był to również wartościowy czas zbierania informacji i opinii nauczycieli na temat realizacji zadań edukacji międzykulturowej w szkołach Lubelszczyzny. Potwierdził się niski poziom kompetencji nauczycieli warunkowany głównie niechęcią do podejmowania nowych wyzwań oraz tzw. „brakiem przymusu" w tym zakresie.

Szkoły na Lubelszczyźnie, głównie wiejskie i z małych miast, poszerzają programy kształcenia i wychowania o zagadnienia edukacji regionalnej, międzykulturowej i europejskiej, ale jest to wynikiem zaangażowania świadomych takiej potrzeby nauczycieli bądź realizacji projektu współfinansowanego ze środków unijnych (często przy współpracy z instytucjami pożytku publicznego).

Problem niskiego poziomu kompetencji międzykulturowych nauczycieli, a w związku z tym również ich uczniów, w województwie lubelskim wymaga dalszych badań. Ich celem będzie diagnoza obecnego stanu i jego przyczyn, określenie mocnych i słabych stron nabywania kompetencji międzykulturowych poprzez analizę przypadków (szkół, nauczycieli, uczniów) oraz opracowanie strategii ich kształtowania w oparciu o potencjał kultury materialnej, symbolicznej i społecznej Lubelszczyzny.

wowicki, E. Ogrodzka-Mazur, A. Szczurek-Boruta (red.): Edukacja międzykulturowa w Polsce i na świecie. Katowice 2000, UŚ; J. Nikitorowicz: Kreowanie tożsamości dziecka. Wyzwania edukacji międzykulturowej. Gdańsk 2005, GWP. 


\section{Bibliografia}

Błeszyńska K.: Teoretyczny status edukacji międzykulturowej. W: J. Nikitorowicz, A. Sadowski, D. Misiejuk (red.): Edukacja międzykulturowa. „Pogranicze. Studia Społeczne”, T. XVII, cz. I. Białystok 2011, UwB.

Dąbrowska E.: Osoba animatora i koncepcja jego kształcenia. W: J. Gajda, W. Żardecki (red.): Dylematy animacji kulturalnej. Lublin 2001, UMCS

Dziekanowska M.: Tożsamość regionalna mieszkańców Lubelszczyzny. Raport $z$ badań, W: M. Dziekanowska, J. Styk (red.): Region w koncepcjach teoretycznych $i$ diagnozach empirycznych. Lublin 2008, Perfecta info.

Lewowicki T.: W poszukiwaniu modelu edukacji międzykulturowej. W: T. Lewowicki, E. Ogrodzka-Mazur, A. Szczurek-Boruta (red.): Edukacja międzykulturowa w Polsce i na świecie. Katowice 2000, UŚ.

Nikitorowicz J.: Edukacja regionalna i międzykulturowa. Warszawa 2009, WAiP.

Nikitorowicz J.: Kreowanie tożsamości dziecka. Wyzwania edukacji międzykulturowej. Gdańsk 2005, GWP.

Sielatycki M.: Kompetencje nauczyciela w Unii Europejskiej. „Trendy. Uczenie się w XXI wieku" 2005, nr 3.

Świdzińska A.: Akademickie ksztatcenie pedagogów wobec perspektywy wielokulturowości. W: A. Paszko (red.): Edukacja międzykulturowa w Polsce wobec nowych wyzwań. Kraków 2011, Stowarzyszenie Willa Decjusza.

\section{Selected contexts of intercultural education in the region of Lublin}

\section{Summary}

What the article explores are two ways of introducing and developing the tasks of intercultural education in Lublin area. The first concerns practical activities conducted in schools at different levels of education. The second way deals with the concept of post-graduate studies in European, regional and intercultural education, carried out in the Institute of Pedagogy of the Maria Curie-Skłodowska's University. The study also contains reflection on possible applications of the po- 
tentialities of the local (material, symbolic, social) culture in constructing authorial school projects and curricula which fulfill the aims of intercultural education.

Key words: local culture, regional education, intercultural education

Translated by Agata Cienciała 